\title{
Which Renewable Energy Consumption Is More Efficient by Fuzzy Edas Method Based on Pestle Dimensions
}

\section{Ozgur DEMIRTAS}

Kayseri Universitesi

\section{Omer Faruk DERINDAG}

Inonu Universitesi

Fulya Zaralı

Kayseri Universitesi

\section{Oguz Ocal}

Kayseri Universitesi

Alper Aslan ( $\nabla$ alperaslan@erciyes.edu.tr )

Erciyes Universitesi https://orcid.org/0000-0003-1408-0921

\section{Research Article}

Keywords: Analytical Hierarchy Process, Planning, Renewable energy

Posted Date: February 8th, 2021

DOI: https://doi.org/10.21203/rs.3.rs-156840/v1

License: (c) (1) This work is licensed under a Creative Commons Attribution 4.0 International License. Read Full License

Version of Record: A version of this preprint was published at Environmental Science and Pollution Research on March 9th, 2021. See the published version at https://doi.org/10.1007/s11356-021-13310-0. 


\title{
WHICH RENEWABLE ENERGY CONSUMPTION IS MORE EFFICIENT BY FUZZY EDAS METHOD BASED ON PESTLE DIMENSIONS?
}

Ozgur DEMIRTAS, Kayseri University, Develi Faculty of Social And Human Sciences demirtasozgur@yahoo.com

Omer Faruk DERINDAG, Inonu University · International Trade and Business https://orcid.org/0000-0002-6693-0628 omer.derindag@inonu.edu.tr

Fulya ZARALI, Kayseri University, Develi Hüseyin Şahin Vocational School fzarali@kayseri.edu.tr

Oguz OCAL, Kayseri University, Faculty of Applied Sciences, oguzocal@kayseri.edu.tr Alper ASLAN Prof. Dr. Erciyes University, Faculty of Aeronautics and Astronautics, Department of Aviation Management, Kayseri, Turkey alperaslan@erciyes.edu.tr

\begin{abstract}
Energy planning contains a continuous process to reassess alternative energy strategies. The authorities responsible for energy planning and management have to adjust their strategies to new and improved alternative resources according to sustainability criteria. The most efficient forms of renewable energy such as geothermal, solar, wind, hydroelectricity and biomass. In this paper, Analytical Hierarchy Process (APH) is employed to see the best renewable energy resources by taking Political, Economic, Social, Technological, Legal and Environmental dimensions into account. We concluded that the most efficient use of renewable energy alternatives is based on Political, Economic, Social, Technological, Legal and Environmental different dimensions, from the most effective to the least effective such as geothermal, solar, biomass, wind and hydropower.
\end{abstract}

Keywords: Analytical Hierarchy Process, Planning, Renewable energy

\section{Introduction}

Energy resources are an important part of the development of the countries and it is important in the environment, social and political aspects and now it has become one of the most highlighted and discussed global issues (Dornan and Shah, 2016; Ozturk, 2017; Usman et 
al, 2020). With the advancement of technology and the emergence of industrialization in the world, the need for energy sources has been increased with the passage of time. But the energy reserves and the number of reserves available in very country differ because the energy sources depend on the topography of the country. And due to this unequal distribution of the energy sources some major environmental concerns has raised, some serious political conflicts have been raised between the different countries and also the unavoidable dependency of the economy and the social issues (Jenkins et at., 2016). These conflicting situations allow people to find alternative sources of energy for future consumption. But these current and future conflicts of the governments and the environment will lead to a negative consequence and the countries will try to move towards the energy sources that are renewable. To restore and utilize the energy and in this aspect, the renewable energy has become an answer for the planning of the sustainable energy. (Asumadu-Sarkodie, 2016)

This research paper has several unique contributions to the energy literature in different aspects. First of all, the paper is providing a practical model for the selection of renewable energy sources on a broader scale by means of PESTLE analysis. Besides this novel aproach, this study also employs FUZZY-EDAS method for first time in the context of energy optimization criterias. Combining multi-criteria inventory classification and PESTLE technique, this paper satisfying the lack of tools faced by decision makers and stakeholders in the selection of the best renewable energy sources. This research paper that reinforced by the power of mathematics and the macro-environmental perspectives, provides a distinctive contribution and a solid framework on energy selection procedure which is vital for sustainability. The usefulness of a tool also requires a high level of flexibility under various conditions. From this point of view, the study shows an adaptive nature depending on the PESTLE conditions of any region concerned. Apart from the literature, we employ Analytical Hierarchy Process (APH) to see the best energy resources by taking Political, Economic, Social, Technological, Legal and Environmental dimensions into account.

Sustainable development is also known as the consistent development which means that without the loss of the future generations we can meet the needs of the present generation (Ouedraogo, 2017). In other words, sustainable development is to maintain a balance between the growth of the economy and to preserve the environment (Gaffney, 2015). By balancing both the things, we can achieve sustainable development. But when we discuss about the sustainable development and the preservation of the environment, energy is the main factor in this discussion. 
To meet the needs and the requirements of the people of the county in a considerable manner is called the Energy Planning (Hiremath et al, 2007; Demirtas, 2014). But energy planning decisions has other aspects as well, as it involves the process in which balancing of the social and economic aspects and the preservation of the environment and the use of the technology over the space and the time is an important factor. This balance is necessary for the survival of the nature. It was observed and estimated that the consumption of the electricity in the world will reach to an extent by the year 2020 to 24,400 billion $\mathrm{kWh}$. And if we want to select the important parameters of the energy sources and its consumption, the main aspects to look upon these resources are the economy and the environment, since it has been seen that $85 \%$ of the emission of the greenhouse gases are the result of the energy sources of today.

The renewable energy sources that are clean and are cost-effective have become a priority but none of these energy sources alternatively can meet the demands and requirements of the world at its own (Edenhofer et al., 2011). So for the proper consumption of the resources, energy policies should be developed and this problem can be seen as a (MCDM) a multiple criteria decision-making problem and this is a time taking and a strategic process. (Pohekar and Ramachandran, 2004; Cereska, 2016; Aziz, 2016)

In the decision-making process different factors are considered as the qualitative and the quantitative factors. As we find difficulty and complexity while making any decision, this difficulty has become a major problem for the decision-makers while they take decisions to find an alternative solution for the problems to fulfill the needs of the present generation. But when the energy evaluation process is conducted, it must deal with the difficult characteristics and attributes to define and also the components of nature including both the factor, qualitative and quantitative (Albayrak and Erensal, 2004). These evaluations should overcome the problems related to the economy, environment, and technology because these things are not identifiable easily and also has to overcome the socio-economic problems that has affected various groups of the interests and the stakeholders that are needed. To view and solve the difficulties, the Analytical Hierarchy Process (AHP) method is used to define the difficult assessment procedures (Aziz, 2016).

Some criteria in the MCDM is set for the evaluation of the energy issues. These criterions are the economical investment cost, operation, and maintenance cost, fuel cost, net present value, payback period, service life, equivalent annual cost, etc.); technical (efficiency, primary energy ratio, safety, reliability, maturity, etc.); environmental CO2 emission, NOx emission,

111 SO2 emission, particles emission, land use, noise, etc.); and the social (social acceptability, job creation, social benefits, etc.) (Kaya and Kahraman, 2010; Kumar et al., 2017). 
For the consistent ad sustainable development of the country, at both the global and the national level, different alternatives including the long term and the short term that enables to increase the sources of the energy variations and also decrease the dependence of the country on the foreign supply is a must factor to be considered. The renewable sources of the country must be evaluated and observed in a very distinctive and sensitive way and these resources must be evaluated to promote the environment. The main objective and aim of this study are to define the best energy resources for the country for the planning of sustainable energy. To achieve our goals and aims, we used a methodology called the APH, to make criteria for the selection of the alternative sources of energy (Cinelli, 2014).

This article is further categorized into four main sections. In the first section, we will generate a literature review regarding sustainable and renewable energy sources and. In the second section, the methodology of the research is discussed in detail. In the third section, analysis of the data collected during the field study will be presented along with the results discussed in relation to the literature review. In the last section, the strengths and the weakness of the research and the implications and future recommendations will be given.

\section{Literature Review}

\section{PESTLE Analysis}

PESTLE (Political, Economic, Social, Technological, Legal and Environmental) analysis allows comprehensive investigation of the problems that most influence in the development of business activities or projects that they are needed to promote (Espinoza, Proaño, Villavicencio, \& Villegas, 2019). This strategic planning foundation goes beyond the SWOT (Strengths, Weaknesses, Opportunities, and Threats) analysis and provides a broad perspective including social and environmental dimensions that are highly valued by today's societies and non-profit organizations. Therefore, the renewable energy industry also requires macro-level environmental scanning (Grant, 2016) more than other sectors to be consistent with its nature. In this context, the multi-dimensional PESTLE technique employs a robust conceptual framework to secure the sustainable development of renewable energy planning (Koshesh \& Jafari, 2019; Zalengera et al., 2014)

\section{Energy and Sustainability}

144 According to (Bishop et al., 2010), the chief purpose of Sustainable energy systems is to 145 provide cost-effective services along with improving the quality of life. These energy resources 146 are supposed to be very potent as well. The term sustainability is basically an environment- 
147 friendly and cost-effective way to provide resources which can be backed up by the institutional

148 structure of the country. A lot of factors such as cost-effectiveness, industrial and commercial 149 profits, improving the quality of life over-all and eliminating poverty are taken into 150 consideration when thinking about the sustainable resources and their services. (Owusu, 151 Asumadu-Sarkodie, 2016; IAEA et al, 2005). Houck \& Rickerson (2009) This is known as 152 assessing the most proper renewable energy alternative regarding sustainable energy 153 development. While taking all this into account, a very key factor should be focused upon and 154 that is, providing the resources for the overall well-being of the population and not over155 consume the resources. They should be planned and used wisely (Ellaban, Abu-Rub \& 156 Blaabjerg; 2014). If this is taken care of along with easy and diverse access of the energy 157 resources, the system will be successfully sustainable.

\section{Sustainability Indicators for Energy}

160 The system of energies are groundworks for supplying all the chief indicators to build a sustainable environment. (Moldan, Janoušková \& Hák; 2012). There are a number of factors that have to be considered while evaluating the energy use and a correlation between sustainability and human activities is seen. Once the indicators are sorted out, other areas can

164 be looked into. These include the environment, social, technical and financial components (Ellaban, Abu-Rub \& Blaabjerg; 2014). By putting all these together, monitoring, design and development are worked upon. These indicators play an essential role in giving us a whole picture of how each and everything is interlinked. A system has sub-systems and they all interact with each other. Since this is a big network, every minute detail of energy use and its after-effects are evaluated and presented by the help of these indicators, be it short-term or long term, (IAEA et al, 2005). Such a complex structure has to be well-linked and translated because without this, nothing will be of use and there will be stunted growth of the sustainable environment system (Evans, Strezov \& Evans; 2009). The work all-together converges to translate energy related problems and for encouraging institutional dialogue.

An abundance of investigations and studies have been carried out regarding the sustainability indicators (see Table 1). They play a tremendous part in the evaluation of development strategies and planning ahead. After so much work, it was concluded that the energy sources have been categorized into six PESTLE dimensions (Zalengera et al. 2014). A number of researchers put together their work towards the cause. Despite all that literature, very scarce proof comprising of mathematical models for energy sustainability, is there. Here are a few examples of what each researcher concluded. Zhou et al. (2006) highlighted that the 
multifold criteria decision making and energy associated environmental studies have risen since 1995. On another occasion, numerical values were given to specific energy systems in accordance with the indicators and evaluated these under weighting conditions. A comparative study was done by Burton and Hubacek (2007) where his main focus was the cost difference in the small-scale energy technology vs the larger substitutes. This was done keeping the abovementioned four categories in mind. Similarly, Fuzzy AHP and VIKOR methodology played a major role in the planning of renewable energy, by Kumar et al. (2010). Selection of a renewable energy analysis was done by Wang, Guo, Dai \& Chen (2017) by using fuzzy VIKOR approach and it revealed that the best renewable energy alternatives are wind energy and biomass energy types. On doing some research, Afgan et al. (2007) gauged the usage of natural gas in the energy industry. Axiomatic design (AD) and AHP were put into use to filter out the options of the top renewable energy substitute under fuzzy conditions by Kahraman et al. (2009). For some time, the manufacturing industry was facing a problem regarding the energy resource selection; this was solved by Onut et al. (2008) by putting analytic network process (ANP), into use.

Table 1. Assessment Criteria for Sustainable Energy Planning

\begin{tabular}{|c|c|}
\hline Dimensions & Criteria \\
\hline \multirow{3}{*}{ Political } & Governmental Support \\
\hline & Political Stability \\
\hline & Corruption \\
\hline \multirow{4}{*}{ Economic } & Investment Cost \\
\hline & Operation and Maintenance Cos \\
\hline & Service Life \\
\hline & Payback Period \\
\hline \multirow{3}{*}{ Social } & Social Benefits \\
\hline & Social Acceptability \\
\hline & Support for Renewable Energy \\
\hline \multirow{4}{*}{ Technological } & Energy Production Capacity \\
\hline & Technological Maturity \\
\hline & Reliability \\
\hline & Safety \\
\hline \multirow{3}{*}{ Legal } & Environmental Regulations \\
\hline & Compliance with EU Laws \\
\hline & Antitrust Law \\
\hline \multirow{3}{*}{ Environmental } & Weather \& Climate \\
\hline & Pressures from NGO's \\
\hline & Natural Disaster Risks \\
\hline
\end{tabular}


indicators tell us about the effects of the production mechanism of energy and the advantages

202 of the services provided on an over-all economy and its progress. Similarly, the technical indicators are used to evaluate if the institutional structure is fit to provide an effective and efficient energy system. Likewise, different energy systems have distinctive influence on the environment as a whole; the environment indicators are useful to evaluate these effects. The pros and cons of the effects in land, air and water (fresh and marine) are also investigated through these. Lastly, the social indicators; keep tags on the effects on employment opportunities, poverty, community development, culture, pollution, health and demographic transition. (Reddy et al. 2007). In conclusion, these indicators evaluate the effects of energy systems on the nourishment of mankind.

\section{Renewable Energy Sources}

According to (Colak \& Kaya, 2017, Kahraman, Kaya \& Cebi, 2009; Krukanont and Tezuka, 2007; Ozkale, Celik, Turkmen \& Cakmaz, 2017; Tsoutsos et al, 2009), various forms of top renewable energy resources are wind energy, hydropower energy, solar energy, geothermal energy and biomass. Mostly the issue faced in energy sources planning is to preference from different energy resources and the mechanics to be advocated.

According to (Kruger, 2006), geothermal energy is the form of energy which is located and found in the upper part of earth's crust which is $10 \mathrm{~km}$ deep. Mostly, it comes in formation of volcanoes, hot springs and fumaroles. Logically, this energy form has

a lot of potential since it is basically the heat of the earth-beneath its surface. It's mainly found in the outermost layer of the earth i.e. the earth's crust, with an average temperature range of between 20 and $30^{\circ} \mathrm{C} / \mathrm{km}$ depth.

Solar in the other source for energy production. According to Aman et al. (2015) and Lehman \& Nierderle (2006), this form of energy is the cleanest if environment is taken into consideration. The sun is our chief source of solar energy and it has immense potential, logically. Various forms can be derived from it e.g. the solar radiation (thermal) which is dispersed through the clouds cannot be converged but its secondary forms are transitioned further into biomass and thus used for energy production. Hydropower and wind energy can also be generated. On the other side, the direct beam radiation (thermal) can definitely be converged and collected according to Kruger (2006). The amount of energy used globally in a year is much lesser than the solar radiation intercepted by the earth. The solar energy functions as a fusion reactor emanating energy all through the solar system. According to (Assmann et 
al., 2006; Noorollahi, Fadai, Akbarpour Shirazi \& Ghodsipuur, 2016), the amount of radiation received in any space depends upon the available area, geographic location and the weather situation.

Another resource of energy production is the Wind. This comes with its pros and cons e.g. when electricity is generated, $\mathrm{CO} 2, \mathrm{NOx}, \mathrm{SO} 2$, mercury air pollutants and particulate matter is filtered out in comparison to any other conventional power station. On the up-side, most investors and firms also agree on the fact that this form of energy has the lowest hazard and is a sub-category of the green energy (Saygın \& Çetin, 2010; Sen \& Ganguly). Another reason that it became famous within the investment inflow sector is the green signal from the large offshore wind farms, financially (Cristobal, 2011; Kunneke, Mehos, Hillerbrand \& Hermes, 2015). BP Statistical Review of World Energy (2010) also confirms that wind energy is one of the profitable and successful resources considering how most countries of the world are suffering from a financial crisis. Keeping all this information in account, the statistics show wind to be playing an essential role in the production of energy (Kaplan, 2015).

As time is passing, the increase in production and usage of renewable energy is excelling due to various reasons. Hydropower energy is counted as one of the top resources as compared to fossil fuel resources. Even the finest fossil fuel plants can provide up to $50 \%$ efficacy whereas the smaller sized but modern turbines can generate up to $90 \%$ of the energy into electricity. Hydropower is becoming famous with a reason. It has approximately $94 \%$ production rate of renewable energy whereas $20 \%$ overall energy generation. Nowadays, there are a number of reasons why mega projects can't be set up e.g. the sites aren't available easily and issues regarding the environment have to be considered; it is because of those high powered hydroelectric stations which were built approximately a century ago, that we're able to make use of this resource. These generated hundreds of megawatts as compared to the small scale hydropower stations. These have immense potential also because the need and usage of renewable energy and generation of electricity is booming. (Ansel \& Robyns, 2006; Korkovelos et al., 2018; Manders, Hoffken, van der Vleuten, 2016) According to (Yuksek et al., 2006; Bilgili et al., 2018) if the hydro resources are used wisely and successfully, they can help countries be self-sufficient and not dependent on fossil fuel resources.

According to Velden et al. (2008) and Toklu (2017), biomass will have all its resources from the waste products of various industries, such as agriculture and forestry. All of these costeffective products also have an easy access which make them a desirable resource. These organic products e.g. crops and organic wastes, are re-usable and play an essential role in energy 
a resource. These come in all forms i.e. solid (wood-chips and straw) and liquid, (slurry tanks and vegetable oils) and gas (biogas). The liquids can be transitioned into biogas also. (Herbert \& Krishnan, 2016). Biomass is mostly a result of agricultural, municipal, forest waste along with a few crops which can specifically be further used as a resource for fuel. above mentioned energy sources, indicators and criteria.

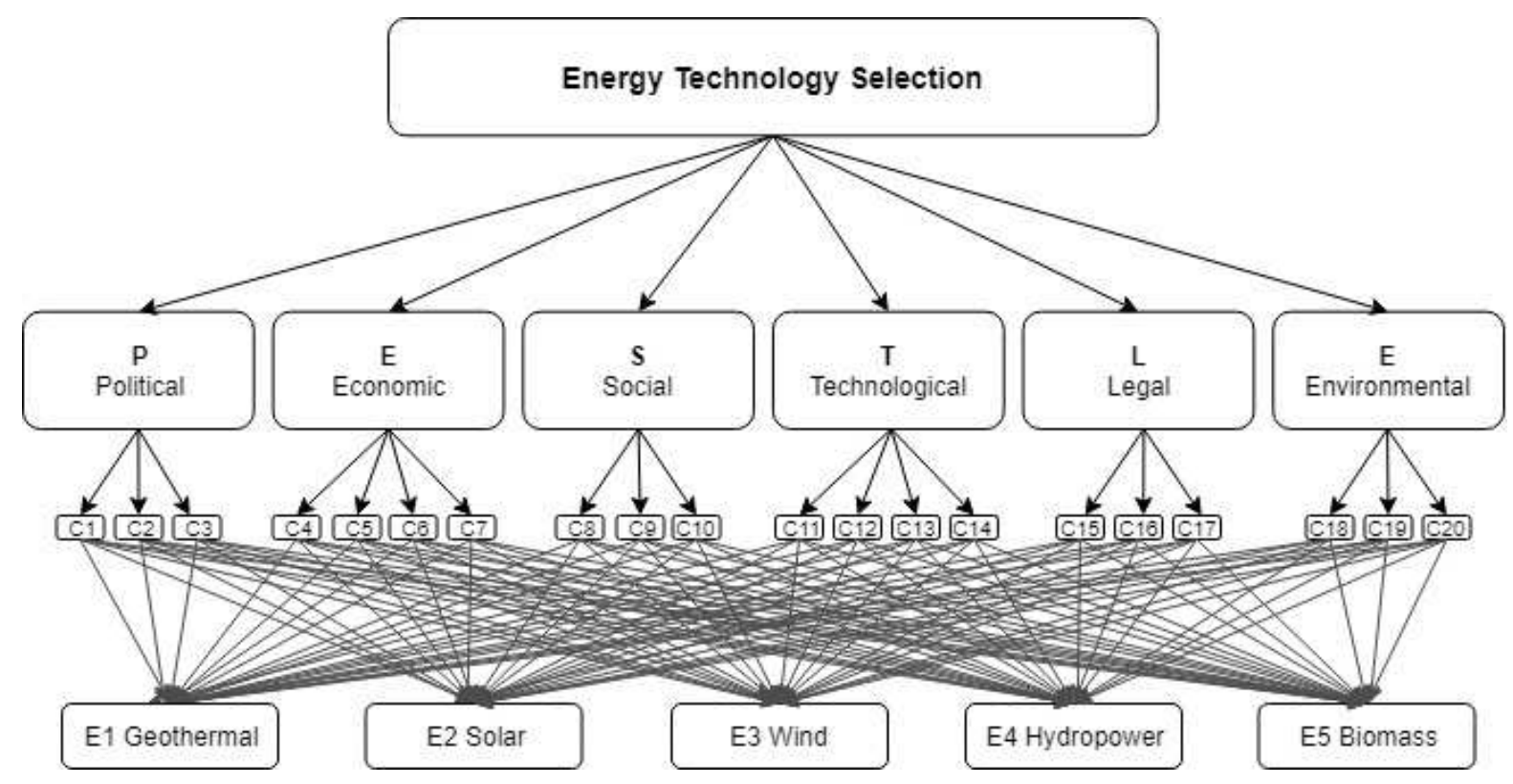

Methodology

In this paper, we used a Fuzzy approach method that is called EDAS in order to select the best renewable energy. Fuzzy set theory was developed by Zadeh (Zadeh, 1965) for handling problems in which information is imprecise, vague, and uncertain. The term "fuzzy" is related to the situation that we have not well-defined boundaries of the set of activities or observations.

283 Some of the definitions related to fuzzy sets and fuzzy numbers, which are used in this research to extend the EDAS method, are stated as follows (Ghorabaee et. all, 2016):

286 Definition 1. A fuzzy subset A of a universal set X can be defined by its membership function $287 \mu_{A}(x)$ as:

$288 A=\left(x, \mu_{A}(x)\right) \mid x \in X$

289 where $x \in X \quad$ denotes the elements belonging to the universal set, and $\mu_{A}(x): X \rightarrow[0,1]$. 
Definition 2. A fuzzy number is a special case of a convex, normalized fuzzy subset $292 \quad\left(\operatorname{sub}_{A}(x)=1\right)$

293 of the real line $R\left(\mu_{A}(x): R \rightarrow[0,1]\right.$.

294

Definition 3. A fuzzy number A is a trapezoidal fuzzy number (TFN) if its membership function 296 is:

$\mu_{A}(x)=\left\{\begin{array}{cl}\frac{\mathrm{x}-\mathrm{a}_{1}}{\mathrm{a}_{2}-\mathrm{a}_{1}} & \mathrm{a}_{1} \leq \mathrm{x} \leq \mathrm{a}_{2} \\ 1 & \mathrm{a}_{2} \leq \mathrm{x} \leq \mathrm{a}_{3} \\ \frac{\mathrm{a}_{4-} \mathrm{x}}{\mathrm{a}_{4}-\mathrm{a}_{3}} & \mathrm{a}_{3} \leq \mathrm{x} \leq \mathrm{a}_{4}\end{array}\right.$ and $\quad$ 0 otherwise

This fuzzy number can also be defined by a quadruplet $A=\left(a_{1}, a_{2}, a_{3}, a_{4}\right)$. An example of this type of fuzzy numbers is shown in figure 1.

Definition 4. A crisp number $k$ can be represented by a trapezoidal fuzzy number $k=(k, k, k$, $315 k)$.

316 Definition 5. Suppose that $A=\left(a_{1}, a_{2}, a_{3}, a_{4}\right)$. and $B=\left(b_{1}, b_{2}, b_{3}, b_{4}\right)$ be two positive 317 trapezoidal fuzzy numbers $\left(a_{1} \geq 0 v e b_{1}>0\right)$ and $k$ is a crisp number. The arithmetic 318 operations with these fuzzy numbers are defined as follows: - Addition: 
- Subtraction:

$A \ominus B=\left(a_{1}-b_{4}, a_{2}-b_{3}, a_{3}-b_{2}, a_{4}-b_{1}\right)$

$A-k=\left(a_{1}-k, a_{2}-k, a_{3}-k, a_{4}-k\right)$

- Multiplication:

$A \otimes B=\left(a_{1} \times b_{1}, a_{2} \times b_{2}, a_{3} \times b_{3}, a_{4} \times b_{4}\right)$

$A \times k=\left\{\begin{array}{l}\left(a_{1} \times k, a_{2} \times k, a_{3} \times k, a_{4} \times k\right) \text { if } k>0 \\ \left(a_{4} \times k, a_{3} \times k, a_{2} \times k, a_{1} \times k\right) \text { if } k<0\end{array}\right.$

- Division:

$A \oslash B=\left(a_{1} / b_{4}, a_{2} / b_{3}, a_{3} / b_{2}, a_{4} / b_{1}\right)$

$A \times k=\left\{\begin{array}{l}\left(a_{1} / k, a_{2} / k, a_{3} / k, a_{4} / k\right) \text { if } k>0 \\ \left(a_{4} / k, a_{3} / k, a_{2} / k, a_{1} / k\right) \text { if } k<0\end{array}\right.$

Definition 6. Let $A=\left(a_{1}, a_{2}, a_{3}, a_{4}\right)$ be a trapezoidal fuzzy number. Then the defuzzified(crisp) value of this fuzzy number can be defined as follows:

$k(A)=\frac{1}{3}\left(a_{1}+a_{2}+a_{3}+a_{4}-\frac{a_{3} a_{4}-a_{1} a_{2}}{\left(a_{3}+a_{4}\right)-\left(a_{1}+a_{2}\right)}\right)$

Definition 7. Suppose that $A=\left(a_{1}, a_{2}, a_{3}, a_{4}\right)$ be a trapezoidal fuzzy number. A function, called psi $(\psi)$, is defined in the following to find the maximum between a trapezoidal fuzzy number and zero.

$\psi(A)= \begin{cases}A & \text { if } k(A)>0 \\ 0 & \text { if } k(A)<0\end{cases}$

Where $0=(0,0,0,0)$

\section{EDAS Method}

As previously stated, the EDAS method was developed by Keshavarz Ghorabaee et al. (2015)

344 for multi-criteria inventory classification. It was also demonstrated that the EDAS method is an e cient method to handle MCDM problems. In this section, an extended version of the EDAS method is proposed to deal with multi-criteria group decision-making problems in the fuzzy en-vironment. In this study, the decision-makers express the weights of criteria and the rating of alternatives with respect to each criterion by linguistic terms. These linguistic terms are quantified by positive trapezoidal fuzzy numbers. Therefore, the concepts and arithmetic operations of the trapezoidal fuzzy numbers are utilized for extending the EDAS method. Suppose that we have a set of $n$ alternatives $\left(A=\left\{A_{1}, A_{2}, \ldots \ldots A_{n}\right\}\right)$ a set of $\mathrm{m}$ criteria $\left(C=\left\{c_{1}, c_{2}, \ldots \ldots c_{n}\right\}\right.$ and 
$352 k$ decision-makers $\left(D=\left\{D_{1}, D_{2}, \ldots \ldots D_{n}\right\}\right)$. The steps of the extended fuzzy EDAS method are

353 presented as follows (Ghorabaee et. all (2016) :

354

355 Step 1: Construct the average decision matrix $(X)$, shown as follows:

$356 \quad X=\left[x_{i j}\right]_{m \times n}$

$357 \quad x_{i j}=\frac{1}{k} \oplus_{p=1}^{k} x_{i j}^{p}$

358 where $x_{i j}^{p}$ denotes the performance value of alternative $A_{i}(1 \leq i \leq n)$ with respect to criterion $c_{j}$

$359(1 \leq j \leq m)$ assigned by the $p$ th decision-maker $(1 \leq p \leq k)$.

360 Step 2: Construct the matrix of criteria weights, shown as follows:

$361 \quad W=\left[w_{j}\right]_{1 \times m}$

$362 w_{j}=\frac{1}{k} \oplus_{p=1}^{k} w_{j}^{p}$

363 where $w_{j}^{p}$ denotes the weight of criterion $c_{j}(1 \leq j \leq m)$ assigned by the $p$ th decision-maker (1 $364 \leq p \leq k)$.

365

366 Step 3: Construct the matrix of criteria weights, shown as follows:

$367 A V=\left[a v_{j}\right]_{1 \times m}$

$368 \quad a v_{j}=\frac{1}{n} \oplus_{p=1}^{k} x_{i j}$

369

370 The elements of this matrix $a v f_{j}$ represents the average solutions with respect to each criterion.

371 Therefore, the dimension of the matrix is equal to the dimension of criteria weights matrix.

372 Step 4: Suppose that $B$ is the set of beneficial criteria and $N$ is the set of non-beneficial criteria.

373 In this step the matrices of positive distance from average (PDA) and negative distance from

374 average (NDA) are calculated according to the type of criteria (beneficial and non-beneficial),

375 shown as follows:

376

$377 P D A=\left[p d a_{i j}\right]_{n \times m}$

$378 N D A=\left[n d a_{i j}\right]_{n \times m}$

379

$380 \quad p d a_{i j}=\left\{\begin{array}{l}\frac{\psi\left(x_{i j} \ominus a v_{j}\right)}{k\left(a v_{j}\right)} \\ \frac{\psi\left(a v_{j} \ominus x_{i j}\right)}{k\left(a v_{j}\right)}\end{array}\right.$ 
$381 \quad n d a_{i j}=\left\{\begin{array}{l}\frac{\psi\left(a v_{j} \ominus x_{i j}\right)}{k\left(a v_{j}\right)} \\ \frac{\psi\left(x_{i j} \ominus a v_{j}\right)}{k\left(a v_{j}\right)}\end{array}\right.$

382

383

384 385

386

387

388

389

390

391

392

393

394

395

396

397

398

399

400

401

402

403

404

405

406

407

408

409

410

where $p d a_{i j}$ and $n d a_{i j}$ denote the positive and negative distance of performance value of $i t h$ alternative from the average solution in terms of $j$ th criterion, respectively.

Step 5: Calculate the weighted sum of positive and negative distances for all alternatives, shown as follows:

$$
\begin{aligned}
& s p_{i}=\bigoplus_{j=1}^{m}\left(w_{j} \otimes p d a_{i j}\right) \\
& s n_{i}=\bigoplus_{j=1}^{m}\left(w_{j} \otimes n d a_{i j}\right)
\end{aligned}
$$

Step 6: The normalize values of $s p \mathrm{e}_{i}$ and $s n \mathrm{f}_{i}$ for all alternatives are calculated as follows:

$n s p_{i}=\frac{s p_{i}}{\max _{i}\left(k\left(s p_{i}\right)\right)}$

$$
n s n_{i}=1-\frac{s n_{i}}{\max _{i}\left(k\left(s n_{i}\right)\right)}
$$

Step 7: Calculate the appraisal score $\left(a_{s} e_{i}\right)$ for all alternatives, shown as follows:

$a s_{i}=\frac{1}{2}\left(n s p_{i} \oplus n s n_{i}\right)$

Step 8: Rank the alternatives according to the decreasing values of appraisal scores $\left(a \mathrm{se}_{i}\right)$. In other words, the alternative with the highest appraisal score is the best choice among the candidate alternatives.

\section{Case Study of Energy selection}

In this section, the solution to the energy selection problem is developed with the proposed fuzzy EDAS method. The five energy sources alternatives (E1,E2,E3,E4,E5) were evaluated with 4 experts of the field. While doing this, we used 6 criterias and 20 sub-criterias. The evaluation as shown in Table-2 was being done according to the Chen's (2000) methodology, and the results were given in Table-3. In addition, all of the energy sources were evaluated according to the Table- 3 results, and we obtained Table- 4 results. We used Corruption, Investment Cost, Operation and Maintenance Cost and Natural Disaster Risks as cost criterias. In addition, the others used as benefit criterias. 
Table 2: Verbal variables used in evaluation and triangular fuzzy number equivalents

\begin{tabular}{l|rrr|rrr}
\hline Verbal Variables & \multicolumn{3}{|l|}{$\begin{array}{l}\text { Triangular fuzzy Numbers used } \\
\text { in the evaluation of criteria }\end{array}$} & \multicolumn{2}{l}{$\begin{array}{l}\text { Triangular fuzzy numbers used to } \\
\text { evaluate alternatives }\end{array}$} \\
\hline Very Low (VL) & 0 & 0 & 0,1 & 0 & 0 & 1 \\
\hline Low (L) & 0 & 0,1 & 0,3 & 0 & 1 & 3 \\
\hline $\begin{array}{l}\text { Medium Low } \\
\text { (ML) }\end{array}$ & 0,1 & 0,3 & 0,5 & 1 & 3 & 5 \\
\hline Medium (M) & 0,3 & 0,5 & 0,7 & 3 & 5 & 7 \\
\hline $\begin{array}{l}\text { Medium High } \\
\text { (MH) }\end{array}$ & 0,5 & 0,7 & 0,9 & 5 & 7 & 9 \\
\hline High (H) & 0,7 & 0,9 & 1 & 7 & 9 & 1 \\
\hline Very High (VH) & 0,9 & 1 & 1 & 9 & 1 & 1 \\
\hline
\end{tabular}

412 Table 3: Evaluation of Criterion Weights by Verbal Variables by Four Decision-makers

\begin{tabular}{ccccc}
\hline & KV-1 & KV-2 & KV-3 & KV-4 \\
\hline C1 & H & H & VH & H \\
\hline C2 & H & VH & M & M \\
\hline C3 & VH & H & H & H \\
\hline C4 & H & H & VH & VH \\
\hline C5 & VH & H & H & H \\
\hline C6 & H & H & H & H \\
\hline C7 & H & VH & H & H \\
\hline C8 & VH & H & H & E \\
\hline C9 & H & H & M & M \\
\hline C10 & H & H & VH & VH \\
\hline C11 & H & H & H & H \\
\hline C12 & H & H & H & H \\
\hline C13 & VH & VH & H & VH \\
\hline C14 & H & VH & H & H \\
\hline C15 & H & H & H & H \\
\hline C16 & VH & M & M & H \\
\hline C17 & H & M & M & H \\
\hline C18 & VH & H & L & H \\
\hline C19 & H & M & M & M \\
\hline C20 & L & L & L & L \\
\hline & & & &
\end{tabular}

414 Table 4: Evaluation of Alternatives by Verbal Variables by Four Decision-Makers

\begin{tabular}{|c|c|c|c|c|c|c|c|c|c|c|c|c|c|c|c|c|c|c|c|c|c|}
\hline & \multicolumn{5}{|c|}{ KV1 } & \multicolumn{5}{|c|}{ KV2 } & \multicolumn{6}{|c|}{ KV3 } & \multicolumn{5}{|c|}{ KV4 } \\
\hline & E1 & E2 & E3 & E4 & E5 & E1 & E2 & E3 & E4 & E5 & $\mathrm{E}$ & & 2 & E3 & E4 & E5 & E1 & E2 & E3 & E4 & E5 \\
\hline $\mathrm{C} 1$ & $\mathrm{VH}$ & $\mathrm{H}$ & $\mathrm{VH}$ & $\mathrm{H}$ & $\mathrm{VH}$ & VH & $\mathrm{H}$ & $\mathrm{H}$ & $\mathrm{H}$ & $\mathrm{H}$ & V & $\mathrm{H}$ & & $\mathrm{VH}$ & $\mathrm{L}$ & $\mathrm{VH}$ & $\mathrm{H}$ & $\mathrm{H}$ & $\mathrm{H}$ & M & $\mathrm{H}$ \\
\hline $\mathrm{C} 2$ & $\mathrm{H}$ & $\mathrm{H}$ & $\mathrm{L}$ & $\mathrm{L}$ & M & VH & VH & $\mathrm{L}$ & M & $\mathrm{H}$ & VI & $\begin{array}{ll}\mathrm{H} \\
\mathrm{H}\end{array}$ & & $\mathrm{H}$ & $\mathrm{H}$ & $\mathrm{H}$ & $\mathrm{H}$ & $\mathrm{M}$ & $\mathrm{L}$ & M & $\mathrm{M}$ \\
\hline $\mathrm{C} 3$ & $\mathrm{VH}$ & $\mathrm{H}$ & $\mathrm{H}$ & $\mathrm{H}$ & $\mathrm{L}$ & $\mathrm{H}$ & $\mathrm{H}$ & $\mathrm{H}$ & $\mathrm{M}$ & $\mathrm{H}$ & $\mathrm{H}$ & $\mathrm{H}$ & & $\mathrm{H}$ & $\mathrm{H}$ & $\mathrm{H}$ & $\mathrm{VH}$ & $\mathrm{H}$ & $\mathrm{H}$ & $\mathrm{M}$ & $\mathrm{H}$ \\
\hline $\mathrm{C} 4$ & $\mathrm{H}$ & $\mathrm{H}$ & $\mathrm{M}$ & $\mathrm{H}$ & M & $\mathrm{H}$ & $\mathrm{H}$ & $\mathrm{L}$ & $\mathrm{H}$ & $\mathrm{H}$ & $\mathrm{H}$ & $\mathrm{H}$ & & $\mathrm{H}$ & $\mathrm{H}$ & $\mathrm{VH}$ & $\mathrm{H}$ & $\mathrm{M}$ & $\mathrm{M}$ & M & $\mathrm{H}$ \\
\hline C5 & $\mathrm{H}$ & $\mathrm{H}$ & $\mathrm{H}$ & M & M & $\mathrm{H}$ & $\mathrm{H}$ & $\mathrm{H}$ & $\mathrm{L}$ & $\mathrm{H}$ & $\mathrm{H}$ & V & $\mathrm{JH}$ & $\mathrm{H}$ & $\mathrm{H}$ & $\mathrm{H}$ & $\mathrm{H}$ & $\mathrm{M}$ & M & $\mathrm{M}$ & $\mathrm{H}$ \\
\hline C6 & VH & $\mathrm{H}$ & $\mathrm{H}$ & $\mathrm{L}$ & $\mathrm{L}$ & $\mathrm{H}$ & $\mathrm{H}$ & $\mathrm{H}$ & $\mathrm{H}$ & $\mathrm{H}$ & VI & $\mathrm{H}$ & & $\mathrm{VH}$ & M & $\mathrm{H}$ & $\mathrm{H}$ & $\mathrm{H}$ & $\mathrm{L}$ & $\mathrm{L}$ & $\mathrm{L}$ \\
\hline
\end{tabular}




\begin{tabular}{|c|c|c|c|c|c|c|c|c|c|c|c|c|c|c|c|c|c|c|c|c|}
\hline C7 & $\mathrm{H}$ & $\mathrm{H}$ & $\mathrm{L}$ & $\mathrm{L}$ & $\mathrm{L}$ & $\mathrm{H}$ & VH & M & M & $\mathrm{H}$ & $\mathrm{H}$ & $\mathrm{H}$ & $\mathrm{H}$ & L & $\mathrm{VH}$ & $\mathrm{VH}$ & M & M & $\mathrm{H}$ & M \\
\hline $\mathrm{C} 8$ & $\mathrm{H}$ & $\mathrm{H}$ & M & $\mathrm{L}$ & $\mathrm{L}$ & $\mathrm{H}$ & $\mathrm{H}$ & M & $\mathrm{L}$ & $\mathrm{H}$ & $\mathrm{VH}$ & $\mathrm{H}$ & $\mathrm{H}$ & $\mathrm{M}$ & $\mathrm{H}$ & $\mathrm{VH}$ & $\mathrm{M}$ & $\mathrm{H}$ & $\mathrm{M}$ & $\mathrm{M}$ \\
\hline C9 & $\mathrm{H}$ & $\mathrm{H}$ & $\mathrm{M}$ & $\mathrm{M}$ & $\mathrm{M}$ & $\mathrm{H}$ & $\mathrm{H}$ & $\mathrm{M}$ & M & $\mathrm{M}$ & $\mathrm{H}$ & $\mathrm{H}$ & $\mathrm{H}$ & $\mathrm{M}$ & $\mathrm{H}$ & $\mathrm{H}$ & $\mathrm{M}$ & $\mathrm{M}$ & $\mathrm{M}$ & $\mathrm{H}$ \\
\hline C10 & $\mathrm{VH}$ & $\mathrm{VH}$ & $\mathrm{H}$ & $\mathrm{H}$ & $\mathrm{H}$ & $\mathrm{H}$ & $\mathrm{H}$ & $\mathrm{H}$ & $\mathrm{H}$ & $\mathrm{M}$ & $\mathrm{H}$ & $\mathrm{VH}$ & $\mathrm{H}$ & $\mathrm{H}$ & $\mathrm{VH}$ & $\mathrm{H}$ & $\mathrm{H}$ & $\mathrm{H}$ & $\mathrm{H}$ & $\mathrm{H}$ \\
\hline C11 & $\mathrm{VH}$ & $\mathrm{H}$ & $\mathrm{H}$ & $\mathrm{L}$ & $\mathrm{H}$ & $\mathrm{VH}$ & $\mathrm{H}$ & $\mathrm{H}$ & $\mathrm{M}$ & $\mathrm{M}$ & $\mathrm{VH}$ & $\mathrm{H}$ & $\mathrm{H}$ & M & $\mathrm{VH}$ & $\mathrm{H}$ & $\mathrm{H}$ & $\mathrm{L}$ & $\mathrm{H}$ & $\mathrm{H}$ \\
\hline C12 & $\mathrm{H}$ & $\mathrm{H}$ & $\mathrm{H}$ & $\mathrm{L}$ & $\mathrm{L}$ & $\mathrm{H}$ & $\mathrm{H}$ & $\mathrm{H}$ & $\mathrm{L}$ & $\mathrm{H}$ & $\mathrm{H}$ & $\mathrm{H}$ & $\mathrm{VH}$ & $\mathrm{M}$ & $\mathrm{H}$ & $\mathrm{VH}$ & $\mathrm{H}$ & $\mathrm{M}$ & $\mathrm{H}$ & $\mathrm{H}$ \\
\hline C13 & $\mathrm{VH}$ & $\mathrm{H}$ & $\mathrm{H}$ & $\mathrm{L}$ & $\mathrm{L}$ & $\mathrm{H}$ & $\mathrm{VH}$ & M & M & $\mathrm{M}$ & $\mathrm{H}$ & $\mathrm{H}$ & $\mathrm{H}$ & M & $\mathrm{VH}$ & $\mathrm{H}$ & $\mathrm{M}$ & M & M & M \\
\hline C14 & $\mathrm{H}$ & $\mathrm{H}$ & $\mathrm{H}$ & $\mathrm{L}$ & $\mathrm{L}$ & $\mathrm{VH}$ & $\mathrm{H}$ & $\mathrm{M}$ & $\mathrm{H}$ & $\mathrm{H}$ & $\mathrm{VH}$ & $\mathrm{H}$ & $\mathrm{VH}$ & $\mathrm{L}$ & $\mathrm{H}$ & $\mathrm{H}$ & $\mathrm{M}$ & $\mathrm{L}$ & $\mathrm{L}$ & $\mathrm{H}$ \\
\hline C15 & $\mathrm{H}$ & $\mathrm{H}$ & $\mathrm{VH}$ & $\mathrm{VH}$ & $\mathrm{VH}$ & $\mathrm{H}$ & $\mathrm{VH}$ & $\mathrm{H}$ & $\mathrm{M}$ & $\mathrm{M}$ & $\mathrm{H}$ & $\mathrm{H}$ & $\mathrm{H}$ & $\mathrm{M}$ & $\mathrm{VH}$ & $\mathrm{H}$ & $\mathrm{H}$ & $\mathrm{M}$ & $\mathrm{H}$ & $\mathrm{H}$ \\
\hline C16 & $\mathrm{VH}$ & $\mathrm{H}$ & $\mathrm{H}$ & $\mathrm{H}$ & $\mathrm{H}$ & $\mathrm{VH}$ & $\mathrm{H}$ & $\mathrm{H}$ & $\mathrm{M}$ & $\mathrm{M}$ & $\mathrm{VH}$ & $\mathrm{H}$ & $\mathrm{L}$ & $\mathrm{H}$ & $\mathrm{VH}$ & $\mathrm{VH}$ & $\mathrm{M}$ & $\mathrm{M}$ & $\mathrm{H}$ & $\mathrm{H}$ \\
\hline C17 & $\mathrm{H}$ & $\mathrm{H}$ & $\mathrm{VH}$ & $\mathrm{H}$ & $\mathrm{L}$ & $\mathrm{H}$ & $\mathrm{L}$ & $\mathrm{H}$ & $\mathrm{M}$ & $\mathrm{M}$ & $\mathrm{H}$ & $\mathrm{M}$ & $\mathrm{M}$ & $\mathrm{M}$ & $\mathrm{H}$ & $\mathrm{H}$ & $\mathrm{H}$ & $\mathrm{H}$ & $\mathrm{H}$ & $\mathrm{H}$ \\
\hline C18 & $\mathrm{H}$ & $\mathrm{H}$ & $\mathrm{H}$ & $\mathrm{H}$ & $\mathrm{H}$ & $\mathrm{VH}$ & M & $\mathrm{M}$ & $\mathrm{M}$ & $\mathrm{M}$ & $\mathrm{H}$ & $\mathrm{L}$ & M & $\mathrm{H}$ & M & $\mathrm{H}$ & $\mathrm{H}$ & $\mathrm{L}$ & $\mathrm{H}$ & $\mathrm{M}$ \\
\hline C19 & $\mathrm{VH}$ & $\mathrm{H}$ & $\mathrm{VH}$ & $\mathrm{H}$ & $\mathrm{H}$ & $\mathrm{VH}$ & $\mathrm{M}$ & $\mathrm{H}$ & $\mathrm{H}$ & $\mathrm{H}$ & $\mathrm{H}$ & $\mathrm{H}$ & $\mathrm{M}$ & $\mathrm{M}$ & $\mathrm{H}$ & ÇH & $\mathrm{H}$ & $\mathrm{M}$ & $\mathrm{H}$ & $\mathrm{M}$ \\
\hline $\mathrm{C} 20$ & $\mathrm{H}$ & $\mathrm{L}$ & $\mathrm{H}$ & $\mathrm{H}$ & $\mathrm{H}$ & $\mathrm{H}$ & $\mathrm{H}$ & $\mathrm{M}$ & $\mathrm{H}$ & $\mathrm{M}$ & $\mathrm{H}$ & $\mathrm{H}$ & $\mathrm{H}$ & M & M & $\mathrm{H}$ & $\mathrm{M}$ & $\mathrm{M}$ & $\mathrm{M}$ & $\mathrm{M}$ \\
\hline
\end{tabular}

416 The fuzzy values and the fuzzy criterion weights of the alternatives evaluated by the 417 decision-makers were combined using Equation 14 and Equation 16, respectively, and are given 418 in Table 5.

Table 5: Combined Fuzzy Criterion Weights

\begin{tabular}{cccc}
\hline Criterias & \multicolumn{3}{c}{ Criteria Weights } \\
\hline $\mathrm{C} 1$ & 0,75 & 0,93 & 0,33 \\
\hline $\mathrm{C} 2$ & 0,55 & 0,73 & 0,63 \\
\hline $\mathrm{C} 3$ & 0,75 & 0,93 & 0,33 \\
\hline $\mathrm{C} 4$ & 0,80 & 0,95 & 0,55 \\
\hline $\mathrm{C} 5$ & 0,75 & 0,93 & 0,33 \\
\hline $\mathrm{C} 6$ & 0,70 & 0,90 & 0,10 \\
\hline $\mathrm{C} 7$ & 0,75 & 0,93 & 0,33 \\
\hline $\mathrm{C} 8$ & 0,65 & 0,83 & 0,48 \\
\hline $\mathrm{C} 9$ & 0,50 & 0,70 & 0,40 \\
\hline $\mathrm{C} 10$ & 0,80 & 0,95 & 0,55 \\
\hline $\mathrm{C} 11$ & 0,70 & 0,90 & 0,10 \\
\hline $\mathrm{C} 12$ & 0,70 & 0,90 & 0,10 \\
\hline $\mathrm{C} 13$ & 0,85 & 0,98 & 0,78 \\
\hline $\mathrm{C} 14$ & 0,75 & 0,93 & 0,33 \\
\hline $\mathrm{C} 15$ & 0,70 & 0,90 & 0,10 \\
\hline $\mathrm{C} 16$ & 0,55 & 0,73 & 0,63 \\
\hline $\mathrm{C} 17$ & 0,50 & 0,70 & 0,40 \\
\hline $\mathrm{C} 18$ & 0,58 & 0,73 & 0,38 \\
\hline $\mathrm{C} 19$ & 0,40 & 0,60 & 0,55 \\
\hline $\mathrm{C} 20$ & 0,00 & 0,10 & 0,30 \\
\hline
\end{tabular}


The combined fuzzy values of the alternatives according to each criterion are given in Table 6.

\begin{tabular}{|c|c|c|c|c|c|c|c|c|c|c|c|c|c|c|c|c|c|c|}
\hline \multirow[b]{2}{*}{$\mathrm{C} 1$} & \multicolumn{3}{|c|}{ E1 } & \multicolumn{3}{|c|}{ E2 } & \multicolumn{3}{|c|}{ E3 } & \multicolumn{3}{|c|}{ E4 } & \multicolumn{3}{|c|}{ E5 } & \multicolumn{3}{|c|}{ AV } \\
\hline & 8,5 & 9,75 & 10 & 7 & 9 & 10 & 8 & 9,5 & 10 & 4,25 & 6 & 7,5 & 8 & 9,5 & 10 & 7,15 & 8,75 & 9,5 \\
\hline $\mathrm{C} 2$ & 8 & 9,5 & 10 & 6,5 & 8,25 & 9,25 & 1,75 & 3 & 4,75 & 3,25 & 5 & 6,75 & 5 & 7 & 8,5 & 4,9 & 6,55 & 7,85 \\
\hline C3 & 8 & 9,5 & 10 & 7 & 9 & 10 & 7 & 9 & 10 & 5 & 7 & 8,5 & 5,25 & 7 & 8,25 & 6,45 & 8,3 & 9,35 \\
\hline C5 & 7 & 9 & 10 & 6,5 & 8,25 & 9,25 & 6 & 8 & 9,25 & 3,25 & 5 & 6,75 & 6 & 8 & 9,25 & 5,75 & 7,65 & 8,9 \\
\hline C6 & 8 & 9,5 & 10 & 7 & 9 & 10 & 5,75 & 7,25 & 8,25 & 2,5 & 4 & 5,75 & 3,5 & 5 & 6,5 & 5,35 & 6,95 & 8,1 \\
\hline C9 & 7 & 9 & 10 & 7 & 9 & 10 & 4 & 6 & 7,75 & 3 & 5 & 7 & 5 & 7 & 8,5 & 5,2 & 7,2 & 8,65 \\
\hline $\mathrm{C} 10$ & 7,5 & 9,25 & 10 & 8 & 9,5 & 10 & 7 & 9 & 10 & 7 & 9 & 10 & 6,5 & 8,25 & 9,25 & 7,2 & 9 & 9,85 \\
\hline C11 & 8,5 & 9,75 & 10 & 7 & 9 & 10 & 5,25 & 7 & 8,25 & 3,25 & 5 & 6,75 & 6,5 & 8,25 & 9,25 & 6,1 & 7,8 & 8,85 \\
\hline $\mathrm{C} 12$ & 7,5 & 9,25 & 10 & 7 & 9 & 10 & 6,5 & 8,25 & 9,25 & 2,5 & 4 & 5,75 & 5,25 & 7 & 8,25 & 5,75 & 7,5 & 8,65 \\
\hline C13 & 7,5 & 9,25 & 10 & 6,5 & 8,25 & 9,25 & 5 & 7 & 8,5 & 2,25 & 4 & 6 & 3,75 & 5,25 & 6,75 & 5 & 6,75 & 8,1 \\
\hline C14 & 8 & 9,5 & 10 & 6 & 8 & 9,25 & 4,75 & 6,25 & 7,5 & 1,75 & 3 & 4,75 & 5,25 & 7 & 8,25 & 5,15 & 6,75 & 7,95 \\
\hline C19 & 8,5 & 9,75 & 10 & 6 & 8 & 9,25 & 5,5 & 7,25 & 8,5 & 6 & 8 & 9,25 & 6 & 8 & 9,25 & 6,4 & 8,2 & 9,25 \\
\hline C20 & 7 & 9 & 10 & 4,25 & 6 & 7,5 & 5 & 7 & 8,5 & 5 & 7 & 8,5 & 4 & 6 & 7,75 & 5,05 & 7 & 8,45 \\
\hline
\end{tabular}

Table 6: Decision Matrix 
Using the combined decision matrix obtained, the average solution values of alternatives for each criterion were obtained through Equation 18. Then we gathered Positive Distance Matrix and Negative Distance Matrix via using Equation 19, and 20. The positive and negative distances

Table 7: Positive Distance Values of All Alternatives to Average

\begin{tabular}{|c|c|c|c|c|c|c|c|c|c|c|c|c|c|c|c|}
\hline & \multicolumn{3}{|c|}{ E1 } & \multicolumn{3}{|c|}{ E2 } & \multicolumn{3}{|c|}{ E3 } & \multicolumn{3}{|c|}{ E4 } & \multicolumn{3}{|c|}{ E5 } \\
\hline $\mathrm{C} 1$ & $-0,12$ & 0,12 & 0,34 & 0,00 & 0,00 & 0,00 & $-0,18$ & 0,09 & 0,34 & 0,00 & 0,00 & 0,00 & $-0,18$ & 0,09 & 0,34 \\
\hline $\mathrm{C} 2$ & 0,02 & 0,46 & 0,79 & $-0,21$ & 0,26 & 0,68 & 0,00 & 0,00 & 0,00 & 0,00 & 0,00 & 0,00 & $-0,44$ & 0,07 & 0,56 \\
\hline C3 & 0,00 & 0,00 & 0,00 & 0,00 & 0,00 & 0,00 & 0,00 & 0,00 & 0,00 & $-0,26$ & 0,16 & 0,54 & $-0,22$ & 0,16 & 0,51 \\
\hline $\mathrm{C} 4$ & 0,00 & 0,00 & 0,00 & 0,00 & 0,00 & 0,00 & $-0,13$ & 0,36 & 0,13 & 0,00 & 0,00 & 0,00 & 0,00 & 0,00 & 0,00 \\
\hline C5 & 0,00 & 0,00 & 0,00 & 0,00 & 0,00 & 0,00 & 0,00 & 0,00 & 0,00 & $-0,13$ & 0,36 & 0,13 & 0,00 & 0,00 & 0,00 \\
\hline C6 & $-0,01$ & 0,38 & 0,68 & $-0,16$ & 0,30 & 0,68 & $-0,35$ & 0,04 & 0,43 & 0,00 & 0,00 & 0,00 & 0,00 & 0,00 & 0,00 \\
\hline C7 & $-0,05$ & 0,42 & 0,79 & $-0,21$ & 0,26 & 0,68 & 0,00 & 0,00 & 0,00 & 0,00 & 0,00 & 0,00 & 0,00 & 0,00 & 0,00 \\
\hline C8 & $-0,01$ & 0,43 & 0,77 & $-0,31$ & 0,20 & 0,65 & $-0,46$ & 0,05 & 0,54 & 0,00 & 0,00 & 0,00 & 0,00 & 0,00 & 0,00 \\
\hline C9 & $-0,24$ & 0,26 & 0,68 & $-0,24$ & 0,26 & 0,68 & 0,00 & 0,00 & 0,00 & 0,00 & 0,00 & 0,00 & 0,00 & 0,00 & 0,00 \\
\hline C10 & $-0,27$ & 0,03 & 0,32 & $-0,21$ & 0,06 & 0,32 & 0,00 & 0,00 & 0,00 & 0,00 & 0,00 & 0,00 & 0,00 & 0,00 & 0,00 \\
\hline C11 & $-0,05$ & 0,26 & 0,51 & $-0,24$ & 0,16 & 0,51 & 0,00 & 0,00 & 0,00 & 0,00 & 0,00 & 0,00 & $-0,31$ & 0,06 & 0,42 \\
\hline C12 & $-0,16$ & 0,24 & 0,58 & $-0,23$ & 0,21 & 0,58 & $-0,29$ & 0,10 & 0,48 & 0,00 & 0,00 & 0,00 & 0,00 & 0,00 & 0,00 \\
\hline C13 & $-0,09$ & 0,38 & 0,76 & $-0,24$ & 0,23 & 0,64 & 0,00 & 0,00 & 0,00 & 0,00 & 0,00 & 0,00 & 0,00 & 0,00 & 0,00 \\
\hline C14 & 0,01 & 0,42 & 0,73 & $-0,29$ & 0,19 & 0,62 & 0,00 & 0,00 & 0,00 & 0,00 & 0,00 & 0,00 & $-0,41$ & 0,04 & 0,47 \\
\hline $\mathrm{C} 15$ & $-0,29$ & 0,07 & 0,40 & $-0,23$ & 0,10 & 0,40 & 0,00 & 0,00 & 0,00 & 0,00 & 0,00 & 0,00 & $-0,29$ & 0,01 & 0,31 \\
\hline C16 & $-0,01$ & 0,25 & 0,47 & 0,00 & 0,00 & 0,00 & 0,00 & 0,00 & 0,00 & 0,00 & 0,00 & 0,00 & $-0,33$ & 0,03 & 0,37 \\
\hline C17 & $-0,22$ & 0,25 & 0,65 & 0,00 & 0,00 & 0,00 & $-0,29$ & 0,14 & 0,54 & 0,00 & 0,00 & 0,00 & 0,00 & 0,00 & 0,00 \\
\hline C18 & $-0,11$ & 0,36 & 0,75 & 0,00 & 0,00 & 0,00 & 0,00 & 0,00 & 0,00 & $-0,34$ & 0,17 & 0,63 & 0,00 & 0,00 & 0,00 \\
\hline C19 & $-0,09$ & 0,19 & 0,45 & 0,00 & 0,00 & 0,00 & 0,00 & 0,00 & 0,00 & 0,00 & 0,00 & 0,00 & 0,00 & 0,00 & 0,00 \\
\hline
\end{tabular}


Table 8: Negative Distance Values of All Alternatives to Average

\begin{tabular}{|c|c|c|c|c|c|c|c|c|c|c|c|c|c|c|c|}
\hline \multirow[b]{2}{*}{$\mathrm{C} 1$} & \multicolumn{3}{|c|}{ E1 } & \multicolumn{3}{|c|}{ E2 } & \multicolumn{3}{|c|}{ E3 } & \multicolumn{3}{|c|}{ E4 } & \multicolumn{3}{|c|}{ E5 } \\
\hline & 0,00 & 0,00 & 0,00 & $-0,34$ & $-0,03$ & 0,30 & 0,00 & 0,00 & 0,00 & $-0,04$ & 0,32 & 0,62 & 0,00 & 0,00 & 0,00 \\
\hline $\mathrm{C} 2$ & 0,00 & 0,00 & 0,00 & 0,00 & 0,00 & 0,00 & 0,02 & 0,55 & 0,95 & $-0,29$ & 0,24 & 0,72 & 0,00 & 0,00 & 0,00 \\
\hline $\mathrm{C} 3$ & $-0,17$ & 0,15 & 0,44 & $-0,29$ & 0,09 & 0,44 & $-0,29$ & 0,09 & 0,44 & 0,00 & 0,00 & 0,00 & 0,00 & 0,00 & 0,00 \\
\hline $\mathrm{C} 4$ & $-0,26$ & 0,18 & 0,57 & $-0,39$ & 0,05 & 0,47 & 0,00 & 0,00 & 0,00 & $-0,39$ & 0,05 & 0,47 & $-0,32$ & 0,08 & 0,47 \\
\hline C5 & $-0,26$ & 0,18 & 0,57 & $-0,32$ & 0,08 & 0,47 & $-0,39$ & 0,05 & 0,47 & 0,00 & 0,00 & 0,00 & $-0,39$ & 0,05 & 0,47 \\
\hline C6 & 0,00 & 0,00 & 0,00 & 0,00 & 0,00 & 0,00 & 0,00 & 0,00 & 0,00 & $-0,06$ & 0,43 & 0,82 & $-0,17$ & 0,29 & 0,68 \\
\hline C7 & 0,00 & 0,00 & 0,00 & 0,00 & 0,00 & 0,00 & $-0,29$ & 0,24 & 0,72 & $-0,13$ & 0,40 & 0,83 & $-0,40$ & 0,05 & 0,48 \\
\hline C8 & 0,00 & 0,00 & 0,00 & 0,00 & 0,00 & 0,00 & 0,00 & 0,00 & 0,00 & $-0,01$ & 0,56 & 1,00 & $-0,39$ & 0,11 & 0,58 \\
\hline C9 & 0,00 & 0,00 & 0,00 & 0,00 & 0,00 & 0,00 & $-0,36$ & 0,17 & 0,66 & $-0,26$ & 0,31 & 0,81 & $-0,47$ & 0,03 & 0,52 \\
\hline C10 & 0,00 & 0,00 & 0,00 & 0,00 & 0,00 & 0,00 & $-0,32$ & 0,00 & 0,33 & $-0,32$ & 0,00 & 0,33 & $-0,24$ & 0,09 & 0,39 \\
\hline $\mathrm{C} 11$ & 0,00 & 0,00 & 0,00 & 0,00 & 0,00 & 0,00 & $-0,28$ & 0,11 & 0,47 & $-0,09$ & 0,37 & 0,74 & 0,00 & 0,00 & 0,00 \\
\hline $\mathrm{C} 12$ & 0,00 & 0,00 & 0,00 & 0,00 & 0,00 & 0,00 & 0,00 & 0,00 & 0,00 & 0,00 & 0,48 & 0,84 & $-0,34$ & 0,07 & 0,47 \\
\hline $\mathrm{C} 13$ & 0,00 & 0,00 & 0,00 & 0,00 & 0,00 & 0,00 & $-0,53$ & $-0,04$ & 0,47 & $-0,15$ & 0,42 & 0,88 & $-0,26$ & 0,23 & 0,66 \\
\hline C14 & 0,00 & 0,00 & 0,00 & 0,00 & 0,00 & 0,00 & $-0,36$ & 0,08 & 0,48 & 0,06 & 0,57 & 0,94 & 0,00 & 0,00 & 0,00 \\
\hline C15 & 0,00 & 0,00 & 0,00 & 0,00 & 0,00 & 0,00 & $-0,31$ & 0,02 & 0,35 & $-0,22$ & 0,15 & 0,48 & 0,00 & 0,00 & 0,00 \\
\hline C16 & 0,00 & 0,00 & 0,00 & $-0,37$ & 0,01 & 0,39 & $-0,15$ & 0,26 & 0,61 & $-0,37$ & 0,01 & 0,39 & 0,00 & 0,00 & 0,00 \\
\hline C17 & 0,00 & 0,00 & 0,00 & $-0,30$ & 0,18 & 0,61 & 0,00 & 0,00 & 0,00 & $-0,44$ & 0,04 & 0,50 & $-0,30$ & 0,18 & 0,61 \\
\hline $\mathrm{C} 18$ & 0,00 & 0,00 & 0,00 & $-0,37$ & 0,13 & 0,60 & $-0,26$ & 0,28 & 0,75 & 0,00 & 0,00 & 0,00 & $-0,41$ & 0,13 & 0,63 \\
\hline C19 & 0,00 & 0,00 & 0,00 & $-0,36$ & 0,03 & 0,41 & $-0,26$ & 0,12 & 0,47 & $-0,36$ & 0,03 & 0,41 & $-0,36$ & 0,03 & 0,41 \\
\hline $\mathrm{C} 20$ & $-0,21$ & 0,29 & 0,72 & 0,00 & 0,00 & 0,00 & 0,00 & 0,00 & 0,00 & 0,00 & 0,00 & 0,00 & 0,00 & 0,00 & 0,00 \\
\hline
\end{tabular}


449 Then, using Equation 23 and 24, positive and negative distance values were multiplied by criterion weights and weighted positive and negative

Table 9: Weighted Total Distances, Normalized Values and Evaluation Results

\begin{tabular}{|c|c|c|c|c|c|c|c|c|c|c|c|c|c|c|c|c|}
\hline \multicolumn{4}{|c|}{ spj } & \multicolumn{3}{|c|}{ snj } & \multicolumn{3}{|c|}{ nspj } & \multicolumn{3}{|c|}{ nsnj } & \multicolumn{3}{|c|}{ asj } & \multirow{2}{*}{$\frac{\text { Kasj }}{1,20}$} \\
\hline E1 & $-1,10$ & 3,74 & 3,80 & $-0,53$ & 0,51 & 0,86 & $-0,51$ & 1,74 & 1,77 & 1,26 & 0,75 & 2,16 & 0,38 & 1,25 & 1,96 & \\
\hline $\mathrm{E} 2$ & $-1,79$ & 1,94 & 2,50 & $-1,73$ & 0,42 & 1,59 & $-0,83$ & 0,90 & 1,16 & 1,86 & 0,79 & 1,43 & 0,51 & 0,85 & 1,30 & 0,89 \\
\hline E3 & $-1,13$ & 0,69 & 0,90 & $-2,62$ & 1,48 & 3,09 & $-0,53$ & 0,32 & 0,42 & 2,30 & 0,26 & $-0,07$ & 0,89 & 0,29 & 0,17 & 0,45 \\
\hline E4 & $-0,49$ & 0,60 & 0,60 & $-1,90$ & 3,84 & 4,11 & $-0,23$ & 0,28 & 0,28 & 1,94 & $-0,90$ & $-1,09$ & 0,86 & $-0,31$ & $-0,40$ & 0,05 \\
\hline E5 & $-1,45$ & 0,42 & 1,28 & $-2,64$ & 1,15 & 2,60 & $-0,67$ & 0,19 & 0,59 & 2,31 & 0,43 & 0,42 & 0,82 & 0,31 & 0,51 & 0,55 \\
\hline
\end{tabular}


According to these results, we obtained a raw for alternatives for the given energy sources as $\mathrm{E} 1>\mathrm{E} 2>\mathrm{E} 5>\mathrm{E} 3>\mathrm{E} 4$. Thus, we can say that the best alternatives for this model is E1 (Geothermal Energy).

\section{Discussion and conclusions}

464

465

466

467

468

469

470

471

472

473

474

475

476

477

478

479

480

481

482

483

484

485

486

487

488

Strategic energy planning issues have been popular topic in the energy literature. Energy decisions are crucial for both policy makers and goverments. Since energy has potential impact (positive or negative) on many aspects of authority and on the country welfare, governments must be carefully to eliminate or mitigate (minimize their impact) the negative costs. The renewable energy generally receives financial, institutional or educational support from the many governments. A major challenge for governments in the field of renewable energy is policy consistency about which policy should be chosen. In this paper, which type of renewable energy types is more efficient is analyzed by Analytical Hierarchy Process (APH) method by taking Political, Economic, Social, Technological, Legal and Environmental dimensions into account. As a result of the APH analysis, the efficiencies of renewable energy types are listed as follows from the strongest to the weakest: geothermal, solar, biomass, wind and hydropower.

\section{Funding}

The author(s) received no financial support for the research, authorship, and/or publication of this article.

\section{Author information}

Author notes

\section{Ozgur DEMIRTAS,}

\section{Omer Faruk DERINDAG,}

3.Fulya ZARALI,

4.Oguz OCAL,

5.Alper ASLAN

OD, OFD, FZ, OO and AA contributed equally to this work as co authors

\section{Affiliations}

1. Kayseri University, Develi Faculty of Social And Human Sciences, Kayseri, Turkey.

2. Inonu University, International Trade and Business, Malatya, Turkey.

3. Kayseri University, Develi Hüseyin Şahin Vocational School, Kayseri, Turkey

4. Kayseri University, Faculty of Applied Sciences, Kayseri, Turkey

5. Erciyes University, Faculty of Aeronautics and Astronautics, Department of Aviation Management, Kayseri, Turkey 
Writing - original draft, conceptualization: AA; writing - original draft: OD and OO; data curation: FZ and OFD; supervision, project administration: AA and OD.

\section{Corresponding author}

Correspondence to Alper ASLAN

\section{Ethics declarations}

Ethics approval and consent to participate

Not applicable

\section{Consent for publication}

Not applicable.

Competing interests

The authors declare that they have no competing interests.

\section{Additional information}

\section{Availability of data and materials section}

Not applicable

\section{References}

Afgan NH, Pilavachi PA, and Carvalho MG. (2007). Multi-criteria evaluation of natural gas resources. Energy Policy, 35, 704-713

Albayrak, E., \& Erensal, Y. C. (2004). Using analytic hierarchy process (AHP) to improve human performance: An application of multiple criteria decision making problem. Journal of Intelligent Manufacturing, 15(4), 491-503.

Aman, M. M., Solangi, K. H., Hossain, M. S., Badarudin, A., Jasmon, G. B., Mokhlis, H., ... \& Kazi, S. N. (2015). A review of Safety, Health and Environmental (SHE) issues of solar energy system. Renewable and Sustainable Energy Reviews, 41, 1190-1204.

Ansel, A., Robyns, B., (2006). Modelling and simulation of an autonomous variable speed micro hydropower station. Mathematics and Computers in Simulation, 71, 320-332.

Assmann, D., Laumanns, U. and Uh, D. (2006). Renewable Energy: A Global Review of Technologies, Policies and Martkets. London: Eartscan

Asumadu-Sarkodie, P. A. (2016). A review of renewable energy sources. Civil \& Environmental Engineering, 1-14.

Aziz, N. F. (2016). MCDM-AHP Method in Decision Makings. ARPN Journal of Engineering and Applied Sciences, 1-4.

Begic, F. and Afgan, N.H. (2007). Sustainability assessment tool for the decision making in selection of energy system-Bosnian case, Energy, 32, 1979-1985

Bilgili, M., Bilirgen, H., Ozbek, A., Ekinci, F., \& Demirdelen, T. (2018). The role of hydropower installations for sustainable energy development in Turkey and the world. Renewable Energy, 126, 755-764.

Bishop, J.D.K., Amaratunga, G.A.J., Rodriguez, C. (2010). Linking energy policy, electricity generation and transmission using strong sustainability and co-optimization. Electric Power System Research, 80, 633-641. 
Burton J and Hubacek K. (2007). Is small beautiful? A multicriteria assessment of smallscale energy technology applications in local governments. Energy Policy, 35, 6402-6412.

Cereska, A. (2016). Operating Characteristics Analysis of Rotor Systems Using MCDM Methods. Studies in Informatics and Control, 59-69.

Chang, D.Y. (1992). Extent analysis and synthetic decision. Optimization techniques and applications. Singapore: World Scientific.

Chang, D.Y., (1996). Applications of the extent analysis method on fuzzy AHP. European Journal of Operational Research, 95, 649-655.

Chen, C. T. (2000). Extensions of the TOPSIS for group decision-making under fuzzy environment. Fuzzy sets and systems, 114(1), 1-9.

Cinelli, M., Coles, S. R., \& Kirwan, K. (2014). Analysis of the potentials of multi criteria decision analysis methods to conduct sustainability assessment. Ecological indicators, 46, 138-148.

Colak, M., \& Kaya, I. (2017). Prioritization of renewable energy alternatives by using an integrated fuzzy MCDM model: A real case application for Turkey. Renewable and Sustainable Energy Reviews, 80, 840-853.

Cox A.M, Alwang J, Johnson T.G. (2000). Local preferences for economic development outcomes: analytical hierarchy procedure. Growth and Change Summer, 31, 341-366.

Demirtas, O. (2014). Evaluating the Best Renewable Energy Technology. International Journal of Energy Economics and Policy, 23-33.

Dornan, M., \& Shah, K. (2016). Energy policy, aid, and the development of renewable energy resources in Small Island Developing States. Energy policy, 98:759-767.

Edenhofer, O., Pichs-Madruga, R., Sokona, Y., Seyboth, K., Kadner, S., Zwickel, T., ... \& Matschoss, P. (Eds.). (2011). Renewable energy sources and climate change mitigation: Special report of the intergovernmental panel on climate change. Cambridge University Press.

Ellabban, O., Abu-Rub, H., \& Blaabjerg, F. (2014). Renewable energy resources: Current status, future prospects and their enabling technology. Renewable and Sustainable Energy Reviews, 39, 748-764.

Espinoza, J. A., Proaño, P. A., Villavicencio, J. R., \& Villegas, M. A. (2019). Extending PESTEL technique to neutrosophic environment for decisions making in business management. Neutrosophic Sets \& Systems, 27.

Evans, A., Strezov, V., \& Evans, T. J. (2009). Assessment of sustainability indicators for renewable energy technologies. Renewable and Sustainable Energy Reviews, 13(5), 10821088.

Gaffney, O. (2014). Sustainable development goals: improving human and planetary wellbeing. Global Change Magazine, 82, 20-23.

Ghorabaee, M. K., Zavadskas, E. K., Amiri, M., \& Turskis, Z. (2016). Extended EDAS method for fuzzy multi-criteria decision-making: an application to supplier selection. International journal of computers communications \& control, 11(3), 358-371.

Ghorabaee, M.K, Zavadskas, E. K., Olfat, L., \& Turskis, Z. (2015). Multi-criteria inventory classification using a new method of evaluation based on distance from average solution (EDAS). Informatica, 26(3), 435-451. 
Grant, R. M. (2016). Contemporary strategy analysis: Text and cases edition. John Wiley \& Sons.

Herbert, G. J., \& Krishnan, A. U. (2016). Quantifying environmental performance of biomass energy. Renewable and Sustainable Energy Reviews, 59, 292-308.

Hiremath R.B, Shikha S, Ravindranath N.H. (2007), Decentralized energy planning; modeling and applicationda review. Renewable and Sustainable Energy Reviews;11, 729-752.

Houck, J., \& Rickerson, W. (2009). The sustainable energy utility (SEU) model for energy service delivery. Bulletin of Science, Technology \& Society, 29(2), 95-107.

International Atomic Energy Agency (IAEA) (2005). United Nations Department of Economic and Social Affairs (UNDESA), International Energy Agency (IEA), Eurostat, European Environment Agency (EEA): Energy indicators for sustainable development : Guidelines and methodologies, Vienna,

Jenkins, K., McCauley, D., Heffron, R., Stephan, H., \& Rehner, R. (2016). Energy justice: a conceptual review. Energy Research \& Social Science, 11, 174-182.

Kahraman C, Kaya I, and Cebi S. (2009). A comparative analysis for multiattribute selection among renewable energy alternatives using fuzzy axiomatic design and fuzzy analytic hierarchy process. Energy, 34, 1603-1616.

Kahraman, C., Cebeci, U. ve Ruan, D., (2004). Multi-attribute comparison of catering service companies using fuzzy AHP: The case of Turkey, International Journal of Production Economics 87, 171-184

Kaplan, Y. A. (2015). Overview of wind energy in the world and assessment of current wind energy policies in Turkey. Renewable and Sustainable Energy Reviews, 43, 562-568.

Kaya, T., \& Kahraman, C. (2010). Multicriteria renewable energy planning using an integrated fuzzy VIKOR \& AHP methodology: The case of Istanbul. Energy, 35(6), 25172527.

Kone, A.Ç. and Buke, T. (2007), An Analytical Network Process (ANP) Evaluation of Alternative Fuels for Electricity Generation in Turkey, Energy Policy, 35, 5220-5228.

Korkovelos, A.; Mentis, D.; Siyal, S.H.; Arderne, C.; Rogner, H.; Bazilian, M.; Howells, M.; Beck, H.; De Roo, A. A Geospatial Assessment of Small-Scale Hydropower Potential in Sub-Saharan Africa. Energies 2018, 11, 3100.

Koshesh, O. S., \& Jafari, H. R. (2019). The Environmental Strategic Analysis of Oil \& Gas Industries in the Kurdistan Region Using PESTLE, SWOT and FDEMATEL. Pollution, 5(3), 537-554.

Kruger, P. (2006), Alternative Energy Resources: The Quest for Sustainable Energy. New Jersey: Wiley\&Sons Inc.

Krukanont P, and Tezuka T. (2007), Implications of capacity expansion under uncertainty and value of information: the near-term energy planning of Japan. Energy, 32, 1809-1824

Kumar, A., Sah, B., Singh, A. R., Deng, Y., He, X., Kumar, P., \& Bansal, R. C. (2017). A review of multi criteria decision making (MCDM) towards sustainable renewable energy development. Renewable and Sustainable Energy Reviews, 69, 596-609.

Kunneke, R., Mehos, D. C., Hillerbrand, R., \& Hemmes, K. (2015). Understanding values embedded in offshore wind energy systems: Toward a purposeful institutional and technological design. Environmental Science \& Policy, 53, 118-129. 
Lehman, H., Nierderle, W. (2006), What Policy Approach is Most Effective?. Solar Today, 3437.

Lund, P. D. (2009), Effects of energy policies on industry expansion in renewable energy. Renewable Energy, 34, 53-64.

Manders, T. N., Hoffken, J. I., \& van der Vleuten, E. B. (2016). Small-scale hydropower in the Netherlands: Problems and strategies of system builders. Renewable and Sustainable Energy Reviews, 59, 1493-1503.

Moldan, B., Janoušková, S., \& Hák, T. (2012). How to understand and measure environmental sustainability: Indicators and targets. Ecological Indicators, 17, 4-13.

Noorollahi, E., Fadai, D., Akbarpour Shirazi, M., \& Ghodsipour, S. (2016). Land suitability analysis for solar farms exploitation using GIS and fuzzy analytic hierarchy process (FAHP) — a case study of Iran. Energies, 9(8), 643.

Onut S, Tuzkaya UR, and Saadet N. (2008), Multiple criteria evaluation of current energy resources for Turkish manufacturing industry. Energy Conversion and Management;49, 6, 1480-1492.

Ouedraogo, N. S. (2017). Africa energy future: alternative scenarios and their implications for sustainable development strategies. Energy Policy, 106, 457-471.

Owusu, P. A., \& Asumadu-Sarkodie, S. (2016). A review of renewable energy sources, sustainability issues and climate change mitigation. Cogent Engineering, 3(1), 1167990.

Ozgur, M.A. (2008), Review of Turkey's Renewable Energy Potential. Renewable Energy, 33, 2345-2356

Ozkale, C., Celik, C., Turkmen, A. C., \& Cakmaz, E. S. (2017). Decision analysis application intended for selection of a power plant running on renewable energy sources. Renewable and Sustainable Energy Reviews, 70, 1011-1021.

Ozturk I (2017) Measuring the impact of alternative and nuclear energy consumption, carbon dioxide emissions and oil rents on specific growth factors in the panel of Latin American countries. Prog Nucl Energy 100:71-81

Pohekar SD, \& Ramachandran M. (2004), Application of multi-criteria decision making to sustainable energy planning e a review. Renewable and Sustainable Energy Reviews, 8 , 365-381

Reddy, A. K., Annecke, W., Blok, K., Bloom, D., Boardman, B., Eberhard, A., \& Ramakrishna, J. (2000). Energy and social issues. World Energy Assessment, 44(5).

Saaty, T.L. 1980. The analytic hierarchy process: planning, priority setting, resource allocation. USA: Mcgraw-Hill International Book Company.

Samouilidis J, and Mitropoulos C. (1982), Energy economy models : a survey. European Journal of Operational Research, 25, 200-215.

Saygın, H. and Çetin F. (2010), New Energy paradigm and renewable energy: Turkey's vision. Insight Turkey, 12, 3, 107-128.

Sen, S., \& Ganguly, S. (2017). Opportunities, barriers and issues with renewable energy development-A discussion. Renewable and Sustainable Energy Reviews, 69, 1170-1181.

Soma K. (2003), How to involve stakeholders in fisheries management - a country case study in Trinidad and Tobago. Marine Policy, 27, 47-58. 
Toklu, E. (2017). Biomass energy potential and utilization in Turkey. Renewable Energy, 107, 235-244.

Tsoutsos T, Drandaki M, Frantzeskaki N, Iosifidis E, Kiosses I.(2009), Sustainable energy planning by using multi-criteria analysis application in the island of Crete. Energy Policy, $37,1587-1600$

Ulutas, B.H. (2005), Determination of the appropriate energy policy for Turkey, Energy, 30, 1146-1161.

Usman A. \& Sana Ullah \& Ilhan Ozturk \& Muhammad Zubair Chishti \& Syeda Maria Zafar (2020), Environmental Science and Pollution Research ,Analysis of asymmetries in the nexus among clean energy and environmental quality in Pakistan, 27:20736-20747.

Van de Velden, M., Baeyens, J., \& Boukis, I. (2008). Modeling CFB biomass pyrolysis reactors. Biomass and Bioenergy, 32(2), 128-139.

Wang TC, Liang LJ, Ho CY.(2006), Multi-criteria decision analysis by using fuzzy VIKOR. Proceedings of International Conference on Service Systems and Service Management;2, 901-906.

Wang, Y., Guo, J., Dai, J., \& Chen, C. (2017). A fuzzy VIKOR approach for renewable energy resources selection in China. Revista de la Facultad de Ingeniería, 31(10), 62-77.

World Commission on Environment and Development (WCED) (1987), Our Common Future, Oxford University Press, Oxford.

World Energy Council (2010), Pursuing sustainability: 2010 assesment of country energy and climate policies. London

Yuksek, O., Komurcu, M. I., Yuksel, I., Kaygusuz K., (2006), The role of hydropower in meeting Turkey's electric energy demand. Energy Policy, 34, 17, 3093-3103.

Zadeh, L. A. (1965). Fuzzy sets. Information and control, 8(3), 338-353.

Zalengera, C., Blanchard, R. E., Eames, P. C., Juma, A. M., Chitawo, M. L., \& Gondwe, K. T. (2014). Overview of the Malawi energy situation and A PESTLE analysis for sustainable development of renewable energy. Renewable and Sustainable Energy Reviews, 38, 335347.

Zhou P, Ang BW, ad Poh KL. (2006), Decision analysis in energy and environmental modeling: an update. Energy, 31, 14, 2604-2622. 
Figures

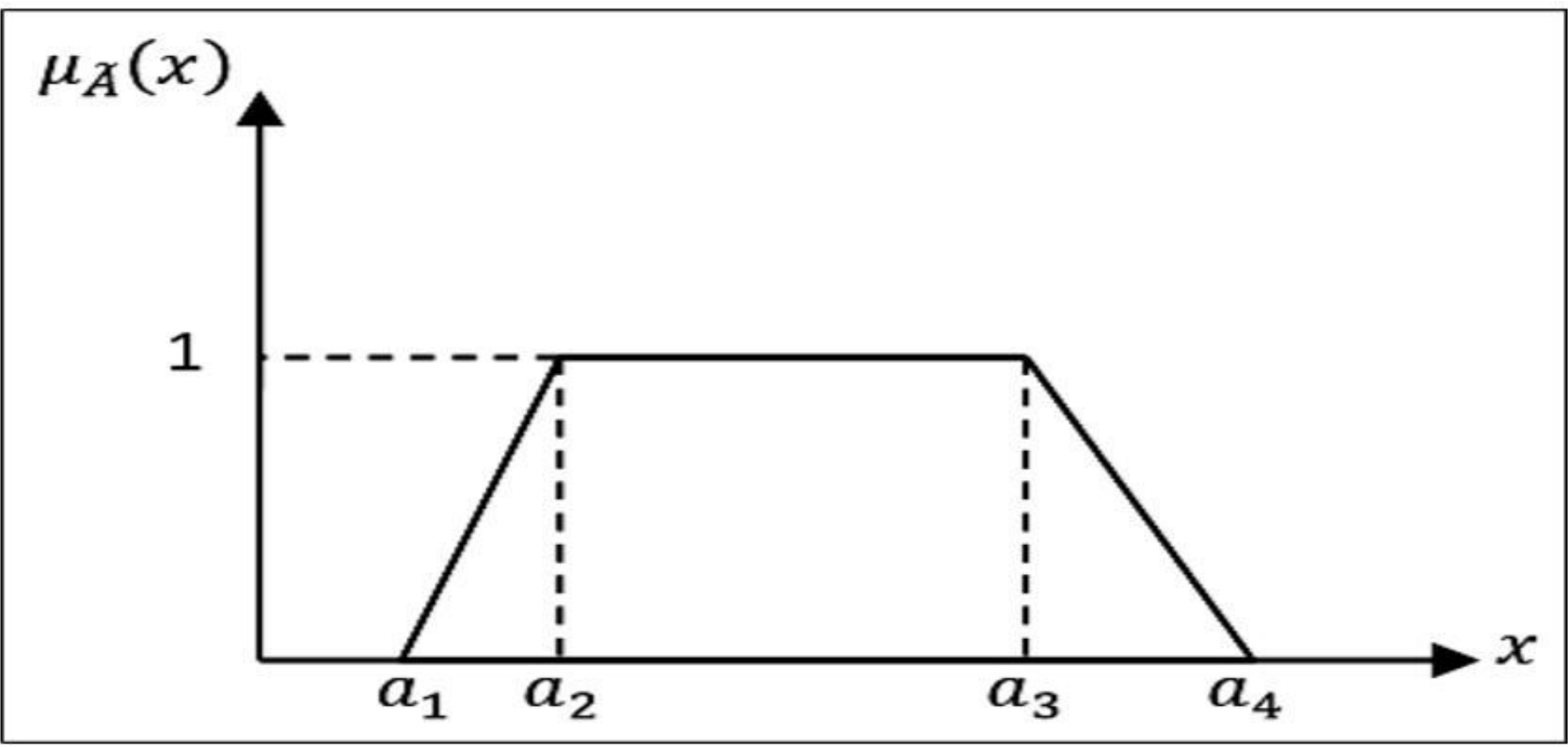

Figure 1

A trapezoidal fuzzy number

\section{Supplementary Files}

This is a list of supplementary files associated with this preprint. Click to download.

- s1.jpg 